\title{
Psychiatric comorbidities in a young man with subacute myelopathy induced by abusive nitrous oxide consumption: a case report
}

This article was published in the following Dove Press journal:

Substance Abuse and Rehabilitation

29 September 2016

Number of times this article has been viewed

\author{
Falk Mancke ${ }^{1,2, *}$ \\ Gintarè Kaklauskaitè ${ }^{\prime} * *$ \\ Jennifer Kollmer ${ }^{3}$ \\ Markus Weiler' \\ 'Department of Neurology, \\ 2Department of General Psychiatry, \\ Center for Psychosocial Medicine, \\ ${ }^{3}$ Department of Neuroradiology, \\ Heidelberg University Hospital, \\ Heidelberg, Germany \\ *These authors contributed equally to \\ this work
}

Correspondence: Falk Mancke Department of General Psychiatry, Center for Psychosocial Medicine, Heidelberg University Hospital,

Voßstraße 2, Heidelberg D-69II5, Germany

$\mathrm{Tel}+4962215635709$

Fax +49 622I 565374

Email falk.mancke@med.uni-heidelberg.de

Markus Weiler

Department of Neurology, Heidelberg

University Hospital, Im Neuenheimer

Feld 400, Heidelberg D-69I20, Germany

Tel +49622I 567504

Fax +49622I 565461

Email markus.weiler@med.uni-

heidelberg.de

\begin{abstract}
Nitrous oxide $\left(\mathrm{N}_{2} \mathrm{O}\right)$, a long-standing anesthetic, is known for its recreational use, and its consumption is on the rise. Several case studies have reported neurological and psychiatric complications of $\mathrm{N}_{2} \mathrm{O}$ use. To date, however, there has not been a study using standardized diagnostic procedures to assess psychiatric comorbidities in a patient consuming $\mathrm{N}_{2} \mathrm{O}$. Here, we report about a 35-year-old male with magnetic resonance imaging confirmed subacute myelopathy induced by $\mathrm{N}_{2} \mathrm{O}$ consumption, who suffered from comorbid cannabinoid and nicotine dependence as well as abuse of amphetamines, cocaine, lysergic acid diethylamide, and ketamine. Additionally, there was evidence of a preceding transient psychotic and depressive episode induced by synthetic cannabinoid abuse. In summary, this case raises awareness of an important mechanism of neural toxicity, with which physicians working in the field of substance-related disorders should be familiar. In fact, excluding $\mathrm{N}_{2} \mathrm{O}$ toxicity in patients with recognized substance-related disorders and new neurological deficits is compulsory, as untreated for months the damage to the nervous system is at risk of becoming irreversible.
\end{abstract}

Keywords: addictive disorders, laughing gas, subacute combined degeneration, substance use disorder, vitamin B12 deficiency

\section{Introduction}

Besides its use in anesthesia, nitrous oxide $\left(\mathrm{N}_{2} \mathrm{O}\right)$ has a long history as a recreational drug. In recent years, an increasing amount of case reports have documented the neurological and psychiatric complications of $\mathrm{N}_{2} \mathrm{O}$ use, and myelopathy has been regarded as the most common manifestation (see for a recent review). ${ }^{1}$ To date, however, there has not been a study using standardized diagnostic procedures to assess psychiatric comorbidities in a patient consuming $\mathrm{N}_{2} \mathrm{O}$. Knowing these comorbidities will help to further characterize the patient population affected, which, in turn, will raise awareness of this mechanism of neural toxicity where it is most relevant.

\section{Case report}

A 35-year-old man presented to the department of neurology at Heidelberg University Hospital reporting a 3-day history of progressive symmetrical numbness in his legs, tingling sensations in his legs and hands, imbalance, and difficulty walking. Past medical history was largely inconspicuous for any physical disorder. The patient further reported a 2-month daily habit of inhaling "laughing gas" of up to 50 whipped-cream capsules, each containing $10 \mathrm{~mL}$ of $100 \% \mathrm{~N}_{2} \mathrm{O}$. He bought these capsules at a supermarket nearby and used a whipped-cream utensil to inhale their contents.

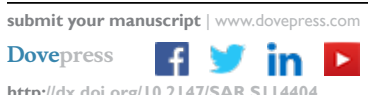


Psychiatric assessment using the Structured Clinical Interview for Diagnostic and Statistical Manual of Mental Disorders, fourth edition, text revision (DSM-IV-TR) and the International Personality Disorder Examination revealed current cannabinoid and nicotine dependence. ${ }^{2,3}$ Starting in his late teenage years, the patient had consumed a variety of psychotropic substances for approximately 10 years. The following substances met the criteria for substance abuse: amphetamines, cocaine, lysergic acid diethylamide, and ketamine (Tables 1 and 2). In addition, the patient's current use of $\mathrm{N}_{2} \mathrm{O}$ fulfilled the $D S M-I V$-TR criteria of substance dependence and there was evidence of a transient psychotic episode lasting for 2 weeks with delusions of persecution following the use of synthetic cannabinoids 8 months back and a cannabinoid-induced depressive disorder lasting for 4 weeks 5 months back.

Neurological examination revealed combined ataxic and pyramidal signs comprising a decreased tactile and vibratory sensation of the legs, a dysmetric heel-to-shin test on both sides, a positive Romberg's sign, a grossly ataxic gait, as well as pathologically brisk tendon reflexes, including bilateral ankle cloni and a slight weakness of the right leg (Medical Research Council [MRC] grade 4+/5). Blood tests revealed a hyperchromic nonanemic macrocytosis, increased bilirubin and alanine aminotransferase (ALT) levels, low levels of vitamin $\mathrm{B}_{12}\left(\mathrm{~B}_{12}\right)$ at $110 \times 10^{-12} \mathrm{~mol} / \mathrm{L}$ (normal, $160-670 \times 10^{-12} \mathrm{~mol} / \mathrm{L}$ ), normal holotranscobalamin, as well as elevated levels of homocysteine at $64.5 \times 10^{-6} \mathrm{~mol} / \mathrm{L}$ (normal, $<12 \times 10^{-6} \mathrm{~mol} / \mathrm{L}$ ), and methylmalonic acid at $3,560 \times 10^{-9} \mathrm{~mol} / \mathrm{L}$ (normal, $50-300 \times 10^{-9} \mathrm{~mol} / \mathrm{L}$ ). Serum antibodies against parietal cells, intrinsic factor, nuclear (anti-nuclear antibody) or neutrophil cytoplasmic epitopes (antineutrophil cytoplasmic antibody [ANCA]), doublestranded DNA, or cardiolipin were not detectable, and rheumatoid factor was normal. Cerebrospinal fluid test results were normal for cell count, glucose, and lactate, yet showed a slight increase of protein concentration at $0.69 \mathrm{~g} / \mathrm{L}$ (normal, $<0.4 \mathrm{~g} / \mathrm{L}$ ). Esophagogastroendoscopy did not reveal any evidence of atrophic gastritis.

Except for nonelicitable tibial nerve somatosensory evoked potentials, neurophysiological test results were all normal; in particular, there were no electroneurographic signs of peripheral neuropathy. A contrast-enhanced cranial magnetic resonance imaging (MRI) scan was normal. However, a spinal MRI showed marked T2W-hyperintense signal alterations confined to the posterior columns of the whole cervical spinal cord without pathological contrast enhancement (Figure 1), also determined as "inverted V" or "rabbit ears" sign. ${ }^{4}$

The patient was diagnosed with subacute combined degeneration of the spinal cord induced by $\mathrm{N}_{2} \mathrm{O}$ consumption and treated with daily intramuscular $\mathrm{B}_{12}$ injections $(1 \mathrm{~g} / \mathrm{d})$, physiotherapy, and methionine tablets $(1 \mathrm{~g} / \mathrm{d}) .^{5}$ Shortly after initiating treatment, partial symptom regression was observed and after 7 days the patient was able to walk without support again. The patient was advised to continue taking $400 \mathrm{mg} \mathrm{B}_{12}$ and $1 \mathrm{~g}$ methionine per day orally for the following 6 months. Psychoeducative interventions regarding the health consequences of $\mathrm{N}_{2} \mathrm{O}$ consumption which the patient was totally unaware of - were conducted, and an addiction-specific outpatient treatment was set in motion.

Table I Fulfilled diagnostic criteria of dependence according to DSM-IV-TR of the individual substances consumed by the patient

\begin{tabular}{llllllll}
\hline Substance & Tolerance & Withdrawal & $\begin{array}{l}\text { Use } \\
\text { despite } \\
\text { harm }\end{array}$ & $\begin{array}{l}\text { Larger/longer } \\
\text { use than } \\
\text { intended }\end{array}$ & $\begin{array}{l}\text { Unsuccessful } \\
\text { desire/effort } \\
\text { to reduce use }\end{array}$ & $\begin{array}{l}\text { Time to obtain } \\
\text { substance or } \\
\text { recover from effects }\end{array}$ & $\begin{array}{l}\text { Reduction of social, } \\
\text { occupational, or } \\
\text { recreational pursuits }\end{array}$ \\
\hline Cannabinoid & $\mathrm{x}$ & - & $\mathrm{x}$ & $\mathrm{x}$ & $\mathrm{x}$ & $\mathrm{x}$ & $\mathrm{x}$ \\
Nicotine & $\mathrm{x}$ & $\mathrm{x}$ & $\mathrm{x}$ & $\mathrm{x}$ & - & - & - \\
Nitrous oxide & $\mathrm{x}$ & - & $\mathrm{x}$ & $\mathrm{x}$ & - & $\mathrm{x}$ & $\mathrm{x}$ \\
\hline
\end{tabular}

Note: Diagnostic criteria of dependence according to DSM-IV-TR ${ }^{19}$ of the individual substances consumed by the patient. An " $x$ ” represents fulfillment and “-” absence of the criterion.

Table 2 Fulfilled diagnostic criteria of abuse according to DSM-IV-TR of the individual substances consumed by the patient

\begin{tabular}{lllll}
\hline Substance & $\begin{array}{l}\text { Recurrent } \\
\text { failure to fulfill } \\
\text { obligations }\end{array}$ & $\begin{array}{l}\text { Recurrent use } \\
\text { when it is physically } \\
\text { hazardous }\end{array}$ & $\begin{array}{l}\text { Recurrent } \\
\text { substance-related } \\
\text { legal problems }\end{array}$ & $\begin{array}{l}\text { Continued use despite } \\
\text { recurrent social or } \\
\text { interpersonal problems }\end{array}$ \\
\hline $\begin{array}{l}\text { Amphetamines } \\
\text { Cocaine }\end{array}$ & $\times$ & $\times$ & - & - \\
$\begin{array}{l}\text { Lysergic acid } \\
\text { diethylamide }\end{array}$ & - & $\times$ & - & - \\
Ketamine & - & - & - & $\times$ \\
\hline
\end{tabular}

Note: Diagnostic criteria of abuse according to DSM-IV-TR'19 of the individual substances consumed by the patient. An " $x$ " represents fulfillment and “-” absence of the criterion. 

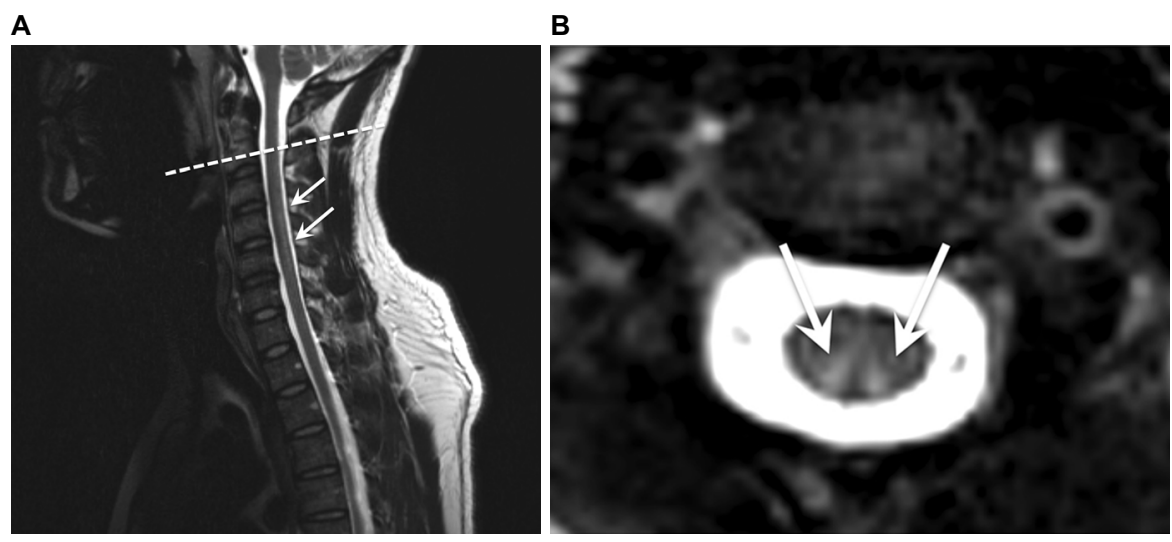

Figure I Sagittal (A) and axial (B) T2W-weighted MRI of the cervical spine revealing marked hyperintense posterior columns.

Notes: The dashed line corresponds to the sectional plane of the axial view. The arrows point to the hyperintense signal of the posterior columns. Abbreviations: T2W, T2-weighted; MRI, magnetic resonance imaging.
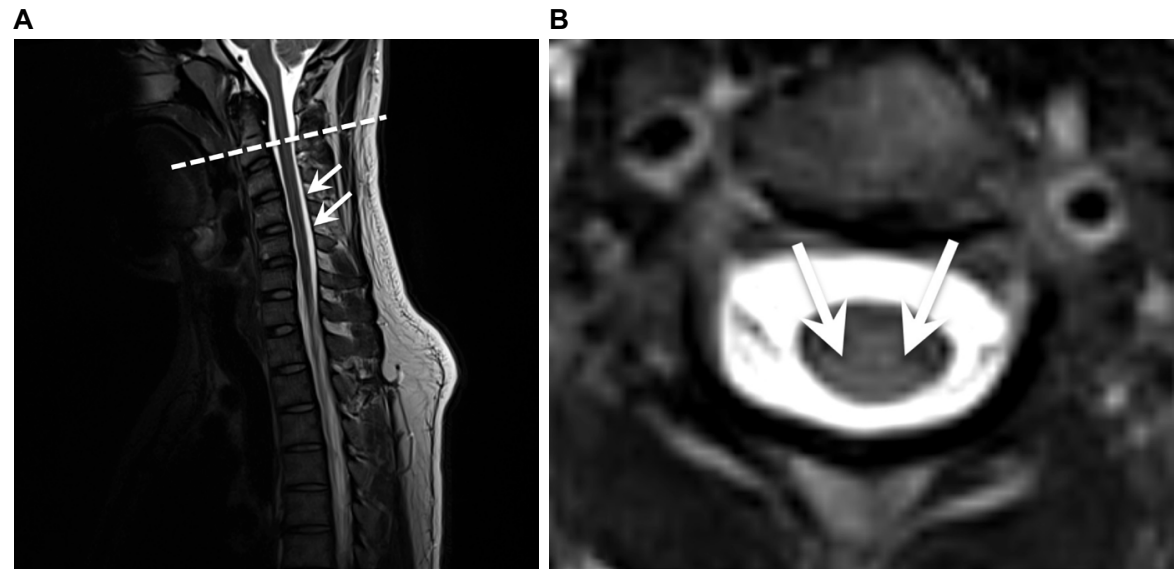

Figure 2 Sagittal (A) and axial (B) T2W-weighted MRI at 6-month follow-up revealing subtotal remission of the posterior columns' signal alterations. Notes: The dashed line corresponds to the sectional plane of the axial view. The arrows point to the former hyperintense signal of the posterior columns. Abbreviations: T2W, T2-weighted; MRI, magnetic resonance imaging.

At 6-month follow-up, the patient had successfully stayed abstinent from $\mathrm{N}_{2} \mathrm{O}$. He reported substantial symptom alleviation enabling him to walk without any restrictions again. The only remaining complaint was a slight numbness of the left hallux. In accordance with the clinical improvement, the tibial nerve somatosensory evoked potentials were back to normal, and an MRI scan revealed subtotal remission of the posterior columns' signal alterations (Figure 2).

\section{Discussion}

For more than 150 years, $\mathrm{N}_{2} \mathrm{O}$ has been widely applied in dentistry and surgery for its analgesic and anesthetic properties. $\mathrm{N}_{2} \mathrm{O}$ as a substance used for recreational purposes has been around for even longer - so-called "laughing gas parties" fueled by $\mathrm{N}_{2} \mathrm{O}$ were particularly popular among the upper-class Londoners back in $1799 .{ }^{6}$

Inhalation of this colorless gas results in a short-lasting "high" and may cause long-lasting harm. $\mathrm{N}_{2} \mathrm{O}$ toxicity includes bone marrow depression, neurological deficits, and an increased risk of coronary heart disease through elevated homocysteine levels. Mechanistically, $\mathrm{N}_{2} \mathrm{O}$ oxidizes the cobalt moiety of $\mathrm{B}_{12}$ resulting in inactivation of the vitamin and inhibition of its action as coenzyme of methionine synthase. ${ }^{7}$ Ultimately, this leads to reduced synthesis of, first, methionine from homocysteine and, second, tetrahydrofolate from methyltetrahydrofolate. Methionine is required for methylation of myelin sheath phospholipids, and its reduced availability causes demyelination and thus myeloneuropathy. ${ }^{8}$ Reduction of tetrahydrofolate leads to disturbed purine biosynthesis eventuating in megaloblastic anemia, among others. In addition to inactivating the $\mathrm{B}_{12}$ metabolism, $\mathrm{N}_{2} \mathrm{O}$ itself has been suggested to possess neurotoxic properties by antagonizing $N$-methyl-D-aspartate receptors and overturning the inhibition of major excitatory pathways possibly damaging cerebrocortical neurons. ${ }^{9}$

In the past, $\mathrm{N}_{2} \mathrm{O}$ misuse had been mainly limited to medical workers due to their easy access to it. According to The Global Drugs Survey 2015, however, $\mathrm{N}_{2} \mathrm{O}$ has become increasingly popular in the party scene worldwide. The current trend combined with the accessibility of $\mathrm{N}_{2} \mathrm{O}$ in whipped-cream 
chargers easily available in the supermarkets and online should be taken as a serious public health risk and addressed accordingly. The patient described here was completely oblivious to the possible negative health consequences of consuming $\mathrm{N}_{2} \mathrm{O}$ owing to the substance being legal in Germany.

In our patient, $\mathrm{N}_{2} \mathrm{O}$ dependence was associated with comorbid cannabinoid and nicotine dependence as well as abuse of amphetamines, cocaine, lysergic acid diethylamide, and ketamine. In line with this, the case study by Gillman as well as other case studies described that $\mathrm{N}_{2} \mathrm{O}$ is very seldom the only drug misused, it rather forms part of a polydrug abuse picture. ${ }^{5,10-13}$ Though conceptually debatable, the relevance of polydrug abuse, ie, the "nonmedical abuse of more than one drug", has long been recognized. ${ }^{14-16}$ For instance, in a sample of adolescents with alcohol abuse, 96\% reported the use of a further drug in addition to alcohol, ${ }^{17}$ and the likelihood of having any (ie, abusive or dependent) alcohol disorder was almost ten times (odds ratio [OR], 9.9) higher given a comorbid substance dependence. ${ }^{15}$ As a whole, these data suggest that the odds of $\mathrm{N}_{2} \mathrm{O}$-related disorders may be substantially higher in patients with comorbid substance use disorders.

Early diagnosis and treatment are crucial as illustrated by a review of 143 patients with $B_{12}$ deficiency that found that the severity of remaining neurological deficits (most commonly ataxia and paresthesias) after treatment was strongly related to the duration as well as the severity of symptoms prior to therapy. ${ }^{16}$ The extent of recovery under treatment in these patients was inversely related to the duration of symptoms.

\section{Conclusion}

This case raises awareness of an important mechanism of neural toxicity, with which physicians working in the field of substance-related disorders should be familiar. In fact, we suggest that excluding $\mathrm{N}_{2} \mathrm{O}$ toxicity in patients with recognized substance-related disorders and new neurological deficits is compulsory, as untreated for months the damage to the nervous system is at risk of becoming irreversible. ${ }^{18}$

\section{Acknowledgment}

The patient provided written informed consent to use the information and images in this case study. The authors acknowledge the financial support of the Deutsche Forschungsgemeinschaft and Ruprecht-Karls-Universität Heidelberg within the funding programme Open Access Publishing. JK was supported by a research grant from the Amyloidosis Foundation.

\section{Disclosure}

The authors report no conflicts of interest in this work.

\section{References}

1. Garakani A, Jaffe RJ, Savla D, et al. Neurologic, psychiatric, and other medical manifestations of nitrous oxide abuse: a systematic review of the case literature. Am J Addict. 2016:25(5):358-369.

2. Loranger AW, Sartorius N, Andreoli A, et al. The international personality disorder examination. The World Health Organization/Alcohol, Drug Abuse, and Mental Health Administration international pilot study of personality disorders. Arch Gen Psychiatry. 1994;51(1):215-224.

3. First M, Spitzer R, Gibbon M, Williams J. Structured Clinical Interview for DSM-IV (SCID). New York, NY: Biometrics Research Department, New York State Psychiatric Institute; 1997.

4. Kumar A, Singh AK. Teaching neuroimage: inverted v sign in subacute combined degeneration of spinal cord. Neurology. 2009;72(1):e4.

5. Butzkueven H, King JO. Nitrous oxide myelopathy in an abuser of whipped cream bulbs. $J$ Clin Neurosci. 2000;7(1):73-75.

6. Jay M. "O, Excellent Air Bag": Humphry Davy and Nitrous Oxide. Available from: http://publicdomainreview.org/2014/08/06/o-excellentair-bag-humphry-davy-and-nitrous-oxide/. Accessed July 19, 2016.

7. Nunn JF. Clinical aspects of the interaction between nitrous oxide and vitamin B12. Br J Anaesth. 1987;59(1):3-13.

8. Louis-Ferdinand RT. Myelotoxic, neurotoxic and reproductive adverse effects of nitrous oxide. Adverse Drug React Toxicol Rev. 1994;13(4):193-206.

9. Jevtović-Todorović V, Todorović SM, Mennerick S, et al. Nitrous oxide (laughing gas) is an NMDA antagonist, neuroprotectant and neurotoxin. Nat Med. 1998;4(4):460-463.

10. Garakani A, Welch AK, Jaffe RJ, Protin CA, McDowell DM. Psychosis and low cyanocobalamin in a patient abusing nitrous oxide and cannabis. Psychosomatics. 2014;55(6):715-719.

11. Ng J, Frith R. Nanging. Lancet. 2002;360(9330):384.

12. Gillman M. Nitrous oxide abuse in perspective. Clin Neuropharmacol. 1992;15(4):297-306.

13. Gillman M. Polydrug abuse associated with nitrous oxide causes death. Oxf Med Case Reports. 2016;2016(6):117.

14. Kaufman E. The abuse of multiple drugs. I. Definition, classification, and extent of problem. Am J Drug Alcohol Abuse. 1976;3(2): 279-292.

15. Stinson FS, Grant BF, Dawson DA, Ruan WJ, Huang B, Saha T. Comorbidity between DSM-IV alcohol and specific drug use disorders in the United States: results from the National Epidemiologic Survey on Alcohol and Related Conditions. Drug Alcohol Depend. 2005;80(1):105-116.

16. Ives R, Ghelani P. Polydrug use (the use of drugs in combination): a brief review. Drugs Educ Prev Policy. 2006;13(3):225-232.

17. Martin CS, Arria AM, Mezzich AC, Bukstein OG. Patterns of polydrug use in adolescent alcohol abusers. Am J Drug Alcohol Abuse. 1993;19(4):511-521.

18. Kumar N. Neurologic aspects of cobalamin (B12) deficiency. Handb Clin Neurol. 2014;120(4):915-926.

19. American Psychiatric Association. Diagnostic and Statistical Manual of Mental Disorders: DSM-IV-TR. Arlington, VA: American Psychiatric Publishing; 2000. 
Substance Abuse and Rehabilitation is an international, peer-reviewed, open access journal publishing original research, case reports, editorials, reviews and commentaries on all areas of addiction and substance abuse and options for treatment and rehabilitation. The manuscript management system is completely online and includes a very quick and fair peer-review system. Visit http://www.dovepress.com/testimonials.php to read real quotes from published authors.

Submit your manuscript here: https://www.dovepress.com/substance-abuse-and-rehabilitation-journal 